\title{
Chapter 2 \\ Peacebuilding in the OSCE \\ Region-An Analysis \\ of the Juxtaposition Between the Conflict \\ Prevention Center with the United \\ Nations Peacebuilding Fund
}

\author{
Maurício Vieira
}

\begin{abstract}
This chapter introduces the perspective on juxtaposition to explain how different international organizations cooperate through similar structural departments. Juxtaposition is presented based on an analysis of a relationship between the United Nations (UN) Peacebuilding Fund (PBF) with the Conflict Prevention Center (CPC) of the Organization for Security and Co-operation in Europe (OSCE) with regard to how these respective institutional departments deal with their own notion on peacebuilding. Through a qualitative analysis on both the PBF and CPC, juxtaposition enables our comprehension to identify peacebuilding dynamics in both organizations and how the UN and the OSCE collectively design strategies aiming peace.
\end{abstract}

Keywords Juxtaposition $\cdot$ OSCE $\cdot$ Peacebuilding $\cdot$ United nations $\cdot$ Conflict prevention

\subsection{Introduction}

In October 2016, the United Nations (UN) Department for Political and Peacebuilding Affairs (DPPA) launched a Liaison Office in Vienna, Austria, in order to deepen the cooperation with the Organization for Security and Co-operation in Europe (OSCE) (DPPA 2020a). The launch of the office was justified based on the need "to advance the Secretary-General's objective of strengthening partnerships under Chapter VIII [of the UN Charter]" (DPPA 2020a), in which the DPPA and the OSCE would be collectively motivated "by the shared goal to strengthen international security and prevent conflicts using multilateral tools and mechanisms of high-level dialogue" (DPPA 2020a).

\footnotetext{
M. Vieira $(\bowtie)$

International Politics and Conflict Resolution, University of Coimbra, Coimbra, Portugal

e-mail: mvieira@upeace.org
}

University for Peace, UN Mandated, San Jose, Costa Rica 
Despite the fact that a partnership between the UN and the OSCE was initiated in 1992 when both international organizations decided to work together in the promotion of peace; launching the office in Vienna is the materialization of a collective effort between the UN-DPPA and the OSCE in the field of international security and prevention of conflicts, based in three main fronts:

First, the UN-OSCE Liaison Office channels expertise from various departments of the UN Secretariat to the OSCE, including by ensuring effective information sharing on relevant peace and security issues as well as relevant policy documents;

Second, the inter-agency forums are regularly organized to facilitate and support high-level and working-level engagements between the OSCE and the UN;

Third, strengthen senior- and working-level engagements between both organizations on various thematic issues on the European continent (DPPA 2020a).

The importance of launching an office in Vienna, as part of a UN's broad role in conflict prevention and peacebuilding, reflects its policy-design embedded in the improvement of its institutional capacity in dealing with emergent conflict needs and, also, on how the UN could benefit from the engagement of different organizations on this issue.

As of writing, Europe is facing the recurrence of hostilities in Eastern Europe, and, among other places, the Nagorno-Karabakh conflict between Armenia and Azerbaijan was - and still is - "one of the several conflicts in the post-Soviet space where the OSCE became involved as a mediator in the peace negotiations" (Gasparyan 2019: 2). Despite the fact that Russia has played a prominent role in the peace process between Armenians and Azerbaijanis in 2020 over the Nagorno-Karabakh territory, the Russian involvement in the conflict had an impact on sidelining not only the Western powers (Roth and Safi 2020) but also the role the OSCE and the UN could play in mediating this conflict. This perspective becomes more comprehensible when taking some historic aspects of this conflict. On the side of the UN, the institution has failed when its involvement intended to bring an end to the fighting among Armenians and Azerbaijanis in 1993 (Bekiarova and Armencheva 2019).

From the OSCE's side, its role through the mediation efforts led by the Minsk Group proved to be not successful in producing a permanent solution to other conflicts, such as in Eastern Ukraine (Askerov 2020, see also chapter by Oberson in this volume). Since the OSCE Minsk Group is co-chaired by the United States, Russia, and France, three of the five UN permanent members of the Security Council, their role is challenged because a sustainable resolution of the conflicts and a peaceful settlement of the conflict puts them in difficult positions, both in the UN Security Council and as members of the Minsk-Group, because they are co-Chairs who were engaging with both sides in the conflict (OSCE 2020e, $\mathrm{f}, \mathrm{g}, \mathrm{h}$ ).

This historical context of the conflict reflects not only that their role in the Minsk Groups was the first conflict-mediation effort undertaken by the OSCE, but that the OSCE failing in this mediation "would hurt the institution's credibility to mediate other conflicts" (Cavanaugh 2017: 5). Cavanaugh's argument goes straightforward in criticizing the role of the Minsk Group, since their engagement proved to be "unable to revitalize the peace process" (Cavanaugh 2017: 1). Such criticism complements what Rácz (2020) points out about the role of multilateral diplomacy in mediating 
the Nagorno-Karabakh conflict. For him, multilateral diplomatic efforts have little chance of achieving a ceasefire, as well, in the case of the OSCE, it "finds itself hamstrung by its model of consensus-based decision-making, which prevents it from acting quickly when an armed conflict erupts between its own member states" (Rácz 2020: 2).

\subsection{Juxtaposition}

Embedded in this challenging scenario of finding a conflict resolution and a peacebuilding niche in and for Europe, both the UN and the OSCE are in what I call a juxtaposition. Juxtaposition, in the scope of this chapter, reflects a dynamic between external offices from, at least, one of the institutions involved in an interchangeable cooperation through a joint-work on expertise, decisions and partnership. In more pragmatic terms, juxtaposition occurs, for example, when the UN establishes a Liaison Office in Vienna to deal exclusively on issues where the OSCE plays a role through its Conflict Prevention Center. Hence, the juxtaposition builds on the UN experience on peace and security to improve its role in the region OSCE has an expertise. As the UN can be considered a peacebuilding actor due to the way the organization coopted the term into its institutional practices and because its peacebuilding role is based in a partnership with its UN agencies, such as FAO, UNICEF, UNWOMEN, UNDP and WFP, this juxtaposition perspective between the $\mathrm{UN}$ and the OSCE reveals another dynamic level of cooperation between international organizations.

Now, the challenge of peacebuilding within the OSCE through its CPC hinges on the fact that it also promotes peacebuilding and post-conflict rehabilitation (OSCE $2020 \mathrm{j}$ ), associating it to a post-conflict phase in which there is a need for a nuanced approach for promoting and achieving peace as a process after the identification of the societal, economic, political and humanitarian chaos. In this case, juxtaposition, here, works as a process of mutual reinforcement of institutional beliefs and practices. Although these three main objectives aim to reinforce UN and OSCE joint work in the field of peace, security and cooperation, I argue that, in the scope of this chapter, the Liaison Office in Vienna represents a UN desire to diffuse its peacebuilding agenda in the OSCE region through mutual sharing and learning from what was conceived by the role of the UN Peacebuilding Fund (PBF). The PBF is an inherent part of the UN Peacebuilding Architecture (PBA), in conjunction with the Peacebuilding Commission (PBC) and the Peacebuilding Support Office (PBSO), which was created in 2005 by the UN Security Council and the UN General Assembly twin-resolutions (UN Doc. S/RES/1645 (2005), UN Doc. A/RES/60/180) to provide financial support to countries facing post-conflict challenges. 
During its functioning since 2005 until October 2020, the UN-PBF allocated funding to 61 countries. ${ }^{1}$ From this list, only seven are OSCE-participating states, namely Albania, Bosnia \& Herzegovina (BiH), Kyrgyzstan, Montenegro, Serbia, Uzbekistan and Tajikistan, and with the inclusion of financial support to Kosovo based on the UN Security Council Resolution 1244 (1999). ${ }^{2}$ Although they represent a limited number in face of the 57 OSCE-participating states at the time of writing, what is in question in this analysis is not how many OSCE-participating States implement peacebuilding projects or programs with funding from the PBF, but that funding allocations by the PBF evidences, on the one hand, a common ground of a UN peacebuilding agenda these OSCE-participating States are being benefited from, and, on the other hand, a dynamic on money flows, which enables a comprehension of which UN-member states are the main ones engaged in financially supporting peacebuilding in the OSCE region. It is important to mention that the PBF, since then, does not provide a role in specific regions, such as the Caucasus or in the conflict involving Azerbaijan and Armenia, when compared to the role of the PBC in the Sahel region of Africa, due to its importance in mitigating environmental degradation and climate change (Sherman and Krampe 2020; Krampe 2019).

However, a scenario for the PB fund could be an important aspect for future engagement in the OSCE region due to the need for building resilience in the context of post-peace agreement among Azerbaijanis and Armenians led by Russia in 2020. Therefore, my point is not that the OSCE plays a role in the functioning of the PBF to some extent, but that there are different levels of juxtaposition in the dynamics in which they co-exist. Such juxtaposition evidences some nuances to what extent the peacebuilding needs of some OSCE-participating States face interference in the construction of a common agenda for recovery and reconstruction through the UN in the OSCE region; and, also, that being an OSCE-participating States is a labelled condition in which such a label cannot be easily detached from these countries even though they interact in different international organizations rather than the OSCE.

\footnotetext{
${ }^{1}$ From this list, 6 countries were exclusive on the agenda of the PBC: Burundi, Central African Republic, Guinea, Guinea-Bissau, Liberia and Sierra Leone; while the remaining ones engaged with the PBF through financial support only, which are: Democratic Republic of the Congo, Côte d'Ivoire, Somalia, Mali, Kyrgyzstan, Sudan, Niger, South Sudan, Yemen, Guatemala, Colombia, Madagascar, Chad, Nepal, Sri Lanka, Papua New Guinea, Myanmar, Burkina Faso, Uganda, Haiti, Gambia, Comoros, Cameroon, Solomon Island, Lebanon, El Salvador, Libya, Mauritania, Honduras, Philippines, BiH, Tajikistan, Togo, Zimbabwe, Bolivia, Ecuador, Nigeria, Albania, Tunisia, Congo, Rwanda, Ethiopia, Kosovo, Uzbekistan, Lesotho, Gabon, Kenya, Benin, Tuvalu, Serbia, Marshall Island, Kiribati, Timor-Leste, Montenegro, Tanzania.

2 The UN Security Council Resolution 1244 (1999) decides and authorizes UN Member States and relevant international organizations to establish the international security presence in Kosovo (UN Doc. S/RES/1244 (1999).
} 


\subsection{Juxtaposition and Peacebuilding}

The notion of juxtaposition between the UN and the OSCE resembles the similarities of the work from the PBF and the OSCE's Conflict Prevention Center (CPC). Nevertheless, before addressing the juxtaposition among them, it is important to point out that, historically, both organizations evidence a common background on juxtaposition through what became conceived of their partnership through the adoption of the UN Security Council Resolution 1631 in 2005. That was the year that the UN established its current Peacebuilding Architecture.

In the 2005 resolution, the UN Security Council expressed its determination to further develop cooperation between the UN and regional organizations, such as the OSCE — but also others such as the EU, AU or OAS - in maintaining international peace and security (OSCE Annual Review 2005 (2006a: 134), UN Doc. S/RES/1631(2005)). Along with their partnership, the OSCE refers to itself as "the largest and most inclusive regional organization under Chapter VIII of the UN Charter" working closely with the UN through political consultations and practical cooperation (OSCE Annual Review 2009 (2010: 105)).

A result is that today the UN and the OSCE work not only in improving their aims collectively, but being pragmatic in furthering "high level political dialogue, as well as working-level synergies, collaborating in a pragmatic, results-oriented manner" (OSCE Annual Review 2013 (2014: 92)). As 2005 was the year UN and OSCE enhanced each other multilaterally officially, 2015 was the year in which this juxtaposition became more pragmatic.

In 2015, the OSCE consolidated its cooperation with the UN in areas such as the conflict cycle, mediation and sustainable development (OSCE Annual Review 2015 (2016: 95)), and in the following year in 2016, enhanced the cooperation among them, focused on priority areas such as peacekeeping and peacebuilding, disarmament and transnational threats, tolerance and non-discrimination, as well as women, peace and security (OSCE Annual Review 2016 (2017: 99).

Cooperation increased over the years, growing also through the number of conflicts. In 2017, the enhanced interaction through the UN Liaison Office on Peace and Security in Vienna contributed to further strengthening working contacts and institutional dialogue (OSCE Annual Review 2017, 2018: 99), and in 2018, the enduring partnership between the UN and the OSCE advanced in a number of strategic areas that are critically important for peace and security in the OSCE region (OSCE Annual Review 2018 (2019: 91)). In 2019, both organizations endorsed the Joint Statement to Supplement the UN-OSCE Framework for Cooperation and Coordination, in which the parties committed to further enhancing their cooperation in the maintenance of international peace and security and the promotion of respect for human rights, fundamental freedoms and the rule of law (OSCE Annual Review 2019 (2020k: 90)).

Against this backdrop and on the evolution of how the UN and OSCE combined their strengthens through juxtaposition over the past decade, it becomes clear that their aims and challenges have an encountering point marked by the applicability of 
the concept of peacebuilding, despite the fact that CPC and PBF were established in different moments in time.

While the CPC was established by the Charter of Paris in 1990, the PBF was embedded in the creation of the UN Peacebuilding Commission in 2005. It is important to emphasize, therefore, that, on the one hand, peacebuilding is a core concept for the functioning of the PBF, since the entire Peacebuilding Architecture was institutionally designed from what became conceived by Boutros Ghali's Agenda for Peace (UN 1992). On the other hand, within the OSCE-CPC, peacebuilding emerges in a fragmented manner, evidencing that $i t$ belongs to a conflict cycle approach within four interrelated phases, namely: early warning, conflict prevention, crisis management and post-conflict rehabilitation.

In essence, peacebuilding is generally defined and institutionally conceived as a holistic approach aiming for peace, with a framework capable of intersecting different levels of engagement in a conflict context. As defined, peacebuilding is a multifaceted task that implies a commitment to establishing the military, legal, political, economic, structural, cultural and psychosocial conditions necessary to promote a culture of peace in opposition to a culture of violence (Lambourne and Herro 2008: 279). The perspective Lambourne and Herro (2008) applies for peacebuilding comes from what Galtung (1976) stated for this concept in the 1970s and on how the UN framed it, making peacebuilding an international policy in which countries facing post-conflict needs would have access to it. In a different point of view, peacebuilding was never mentioned when the establishment of the CPC within the OSCE structure. Nevertheless, the role CPC plays as part of its conflict cycle approach makes peacebuilding a coherent and holistic design for countries in need of "early warning, conflict prevention, crisis management, and post-conflict rehabilitation".

Despite the differences, peacebuilding was conceived by the UN and the OSCE, both organizations deal with peacebuilding in a way that enables applicability of this concept into two complementary frameworks. My argument on this aspect refers to the fact that, within the OSCE, peacebuilding is being put into practice through the Conflict Prevention Center that, in parallel, has the support of the UN through the Peacebuilding Fund (PBF). Since the PBF provides financial support to countries facing post-conflict needs, this financial support the UN controls benefits some of the OSCE-participating States, such as Albania, Bosnia \& Herzegovina, Kyrgyzstan, Montenegro, Serbia, Uzbekistan, Tajikistan and the territory of Kosovo.

\subsection{UN-OSCE Conflict Prevention Center}

The idea of the OSCE Conflict Prevention Centre was established by the Conference on Security and Cooperation in Europe (CSCE) during the Paris Summit ${ }^{3}$ in November 1990. It was as a collective commitment by CSCE-participating States

\footnotetext{
${ }^{3}$ The Paris Summit took place on 19 November 1990 in Paris, and "marked a turning point in the history of the CSCE in the post-Cold War era" (OSCE, 2020j). At the Summit, "the participating
} 
aiming to settle disputes by peaceful means (CSCE 1990: 5). At that time, Europe was facing a collapse as a result of the end of the Cold War, and the CPC emerged more as an agreement between the CSCE-participating States in which it would be required to develop mechanisms for preventing and resolving conflicts among them (CSCE 1990), rather than an institutional practice in the field of peacebuilding at first glance.

As Ackerman (2003) explains, the end of the Cold War was a political aspect that contributed to transforming the CSCE from an international regime to a regional security organization, which made it increasingly engaged in the prevention and management of conflicts. Although its focus was, primarily, at the intrastate level, its preventive capacity role rested on the idea and the necessity to build constructive and cooperative relationships on an interstate level in the Cold War era (Ackerman 2003: 6).

At the beginning of its establishment, the Charter of Paris expressed a desire for an era of democracy, peace and unity in Europe and, within this context, the CPC's design was embedded to provide support with regard to the implementation of confidence and security-building measures (Steinmeier 2016). ${ }^{4}$

Hence, the OSCE-CPC was not established within a specific peacebuilding approach or strategy by the OSCE, which the OSCE never had. Nevertheless, its historical process marked by a transition from the auspices of the CSCE to the OSCE evidences where peacebuilding fits into its functioning. Its aims did not advance the concept of peacebuilding within the CPC nor contribute to it in becoming a peacebuilding actor in Europe. Any OSCE objectives in this matter are embedded in the Ten Principles of the Final Act from 1975, which reaffirmed CSCE-participating states" "commitment to peace, security and justice" (CSCE 1975: 3).

As the Ten Principles are the landmark for comprehending much of the CSCE/OCSE involvement in peace and security issues in Europe, I would affirm that these principles are the first framework for identifying where peacebuilding lies within the CPC. They congregate a holistic approach, varying from respect for the rights inherent in sovereignty, to the inviolability of frontiers, peaceful settlement of disputes, respect for human rights and fundamental freedoms and equal rights and self-determination of peoples (CSCE 1975). In this regard, the establishment of the CPC within the evolution of the CSCE to the OSCE was a process of aligning itself with the purposes and principles of the Charter of the United Nations from 1945 (CSCE 1975: 4).

\footnotetext{
States signed the Charter of Paris for a New Europe, adding an active operational structure to the OSCE role as a forum for negotiation and dialogue" (OSCE 2020j).

${ }^{4}$ That are, first, mechanisms for consultation and co-operation as regards to unusual military activities; secondly, the annual exchange of military information; thirdly, the communications network; fourth, the annual implementation assessment meetings; and fifth, co-operation as regards to hazardous incidents of a military nature (CSCE 1990).
} 


\subsection{Communication Network}

In addition, much of its role, initially conceived through the 1990 Charter of Paris, focused on information sharing rather than any other institutional practice aiming at stability in the region. Such an assumption is corroborated by the fact that a communications network is mentioned as the most successful aim within the CPC since it "complements traditional diplomatic channels with secure and reliable infrastructure that enables information exchange and dialogue" (OSCE 2020j). In the scope of this chapter, information exchange and dialogue among diplomatic fields is one of the main characteristics that enables juxtaposition within international organizations' bureaucratic structures, since this is what posits them side by side in their respective shared roles and partnerships.

At that stage, CPC was limited in providing a broader role for the advancement of the term peacebuilding in the region. An improvement in its role came only when the CSCE faced a transitional phase to the OSCE during the Budapest Summit in 1995. As Cohen points out, while, on the one hand, the 1990 Charter of Paris marked the transition from the OSCE's role as a forum for negotiation in this confrontational era to an organization for security through cooperation and the promotion of democracy; on the other hand, the Budapest Summit Meeting "cast the OSCE as a "primary instrument for early warning, conflict prevention and crisis management', with a 'flexible and dynamic' approach" (Cohen 1999: 8-9).

Evidently, the assertion is that CPC had its role improved while advancing concepts that relate to peacebuilding as a core element for its functioning So far, the OSCE's peacebuilding does not differ from the UN's approach for peacebuilding, Rather the OSCE's design over a conflict cycle is the innovative aspect the organization could contribute to the dynamic of conflict mediation. In this scenario, as Gheciu explains, the OSCE "emerged (...) as the Euro-Atlantic security institution with a clear and innovative mandate to promote a new, cooperative, and inclusive model of security" (2008: 116). Thus the OSCE, in its own regional area, could enable the emergence of new mechanisms, procedures and political instruments to facilitate this role (Cohen 1999: 9).

As Gheciu (2008) argues based on the Charter of Paris, "the security discourse articulated by the OSCE following the end of the Cold War is based on the assumption that the establishment of stable liberal democracies is a key recipe for regional stability and international security" (Gheciu 2008: 116). As the author continues, the OSCE's approach has been similar to, as well as, a source of inspiration to the EU and NATO (Gheciu 2008: 116). And here I include the approach the UN applied for over its 70 years as well, since these institutions have played —and still play—a role on peace, security, political transitions and stability.

Although CPC emerged to work in the pursuit of collective problem-solving in the former-CSCE region, it was not designed to become a static body under its own domain. Following Cohen, the need to develop a more sophisticated conflict prevention capacity necessitated strengthening of the political instruments and organs 
of the CSCE and a reconsideration of the types of intervention that would be feasible (Cohen 1999: 8). ${ }^{5}$

As CPC is inserted in a European political context marked by challenging, mutable and interventionist-driven approach. Embedded on the notion of conflict prevention, crisis management, post-conflict peacebuilding, and peaceful settlement of conflicts (Ackerman 2003: 5). Hence, in order to provide a more elicit explanation of these reasons, one comes to George and McGee, who mentions that the dramatic rise in the conflict that has been seen since the end of the Cold War has burdened the OSCE with "the same challenge as all international organisations" (George and McGee 2006: 81). In this regard, as George and McGee evaluate, what emerged from this period was a new, more sophisticated approach to conflict prevention which entailed creating institutions, structures and tools to address the specific needs of the different stages of the conflict cycle (2006: 84).

The OSCE Budapest Summit in 2006 was the momentum for reforming its structure while providing a more pragmatic role for the challenges Europe was facing with the end of the Cold War. During the Summit, the participating member states of the OSCE enabled an improvement of the CPC into a more pro-active role in peace settlements in the region; an improved CPC scope with the adoption of different conceptualizations to designate its role in a post-conflict European context for rehabilitation.

Evidently, the post-conflict rehabilitation concept for the CPC brought it closer to peacebuilding as a central aspect of its functioning. However, the OSCE has never explicitly outlined what "post-conflict" means and where the lines are drawn between conflict management, conflict settlement and rehabilitation activities (George and McGee 2006: 89). Despite some scholars arguing that there was vagueness in these concepts within the role of the CPC, the process of institutionalizing peacebuilding became expressed in 2011 when the OSCE designed a framework for its role embedded in a conflict cycle approach as it is expressed in the document Elements of the Conflict Cycle, Related to Enhancing the OSCE's Capabilities in Early Warning, Early Action, Dialogue Facilitation and Mediation Support, and Post-Conflict Rehabilitation (OSCE Doc. MC.DEC/3/11). The document is based on the Ministerial Council (MC) Decision 3/11 during the Vilnius Meeting. Once again, the document is an alignment of OSCE's adherence to the Charter of the United Nations (OSCE

\footnotetext{
${ }^{5}$ Since its emergence to date, CPC co-ordinates the activities of the OSCE's field operations, helping to address all phases of the conflict cycle through proactive guidance and advice on relevant tools and instruments (OSCE Annual Report 2005 (2006a): 129; 2007 (2008): 92; 2013 (2014): 43; 2015 (2016): 32); assisting field operations in accordance with respective mandates, being a focal point in the Secretariat for developing the OSCE's role in the politico-military dimension (OSCE Annual Report 2005 (2006a): 129; 2007 (2008): 92; 2013 (2014): 43; 2015 (2016): 32). In addition, the CPC is responsible for supporting the Chairmanship, the OSCE Secretary General and the decision-making bodies in implementing OSCE tasks in the areas of its conflict cycle (OSCE Annual Reports 2005 (2006a: 129); 2007 (2008: 92); 2013 (2012): 43; 2015 (2016): 32; 2016 (2017): 36; 2017 (2018): 32; 2018 (2019): 32; 2019 (2020k): 32), while promoting regional co-operation with other international organizations (OSCE Annual Report 2013 (2014): 43) aiming to find lasting political settlements for existing conflicts (OSCE Annual Report 2019 (2020k: 32)).
} 
Doc. MC.DEC/3/11) and, most importantly, adequacy of its structure in the face of the challenges in Europe.

But mechanisms of early warning, conflict prevention, and crisis management have always been at the core of the OSCE since early 1990s and were not new, and did not go beyond the basic notion of peacebuilding. For Ackermann, such decisions reflected a "timely document, as other international organizations have developed their crisis- and conflict-response capacities over the years, especially in the case of the European Union" (2013: 9), which required a "concrete action by the OSCE Secretary General, in consultation and co-operation with the OSCE Chairmanship and other executive structures" (Ackerman 2013: 9).

\subsection{Peacebuilding Under the CPC Policy}

The OSCE recognizes the need for adequacy in conjunction with the role of the UN on the same issues of peace and security, and builds upon a juxtaposition process with the UN, creating a space where both institutions can provide support to each other since they work under the same conceptualization and institutional approaches. ${ }^{6}$ Conflict prevention, conflict resolution, post-conflict rehabilitation and peace-building strategies involve efforts to address violations of human rights and fundamental freedoms, as well as intolerance and discrimination, and the absence of strong democratic institutions and the rule of law, as highlighted by the OSCE today (OSCE Doc. MC.DEC/3/11, page 2-3).

An illustration of the OSCE involvement in peacebuilding through its conflict cycle approach is, on the one hand, through the inclusion of an early warning approach; and, on the other hand, through the human dimension within the missions the organization deploys. Examples from the OSCE's engagement in Ukraine, Caucasus, Tajikistan - to mention a few-and its role on border issues in Fergana Valley between Kyrgyzstan, Tajikistan and Uzbekistan in Central Asia are an evidence of both perspectives of engagement (OSCE Annual Report 2006a, 2007, 2008, 2009, 2010, 2011, 2012, 2013, 2014, 2015, 2016, 2017, 2018, 2019, 2020k). Nevertheless, the challenge early warning and human dimension posit to the OSCE reveals its issue of concern or, in other terms, its weakness or fragility: on how to deal with mediation on themes and situations that threaten not only the European territory but the organization as a whole. This becomes more visible during the annexation of Crimea by Russia in mid-March 2014. Such an episode came as a surprise to most analysts who concluded that the absence of the OSCE in Crimea was the reason that

\footnotetext{
${ }^{6}$ Such a perspective is corroborated by what peacebuilding embraces for the OSCE's action in both conceptual and pragmatic terms based on Galtung's (1976) contribution, when he enabled a comprehension of the term within three stages in the promotion on peace as an interventionist model: peacekeeping, peacemaking and peacebuilding. Based on his study, the term peacebuilding reflects a different connotation from the previous two, in which it embraces structures that must be found in order to remove the root causes of civil wars and, hence, being capable to offering alternatives to war in situations where wars might occur (Galtung 1976: 298).
} 
made the international community blind and unable to engage in early crisis response on that specific case (Tanner 2016: 242). In the case of the Caucasus, which includes the Nagorno-Karabakh and Georgia/South Ossetia conflicts, the OSCE paved the way forward by trying to capitalize on the momentum for seeking a comprehensive political settlement (Van Hoye 1999: 256). Although the OSCE's role became limited to being an actor capable of providing a direct influence on these issues, its role is now more oriented towards a post-conflict phase in the region. The case of Tajikistan's borders differs to some extent, especially because the OSCE is permanently involved in the training of Tajik, Kyrgyz and Afghan border officials, aiming to detect and intercept illegal border movements and helping them to uncover chemicals used for drug production that are smuggled to Tajikistan from China or Kyrgyzstan (OSCE 20201).

This multidimensional role of the OSCE in these conflict settings above explains the reason for thinking of a juxtaposition within the OSCE-CPC and UN-PBF. This perspective depends on the notion that when the CPC was established in the 1990s, that period was also marked by the institutionalization of the term peacebuilding into the UN roots through what was conceived by Boutros-Ghali's Agenda for Peace in 1992. At that time, peacebuilding was defined in the context of the aftermath of a civil war as an ad continuum strategy responsible for "rebuilding the institutions and infrastructures of nations torn by civil war and strife; and building bonds of peaceful mutual benefit among nations formerly at war" (UN 1992: 2).

Since its emergence in the UN Agenda for Peace, peacebuilding was enlarged by the Brahimi Report which defined it as an activity which is undertaken on the far side of the conflict to reassemble the foundations of peace and provide the tools for building on those foundations something that is more than just the absence of war (UN 2000: 3).

Looking at the above, one can conclude that OSCE-CPC was not built under a peacebuilding approach. But its functioning enhanced an institutional practice on peace through what became conceived as an institutional framework in between the lines, which gain strength when other international organizations enhance the term through their own practices.

\subsection{Juxtaposition in the Field of Peacebuilding}

The rationale behind the juxtaposition in the field of peacebuilding lies on what became conceived in Chapter VIII of the UN Charter from 1945 which delimitates UN involvement with other regional organizations. As the former OSCE SecretaryGeneral Lamberto Zannier in 2015 pointed out, Chapter VIII evidences an encouragement from the side of the UN-member states that have entered into regional arrangements such as the OSCE (Zannier 2015: 97). It makes every effort to achieve pacific settlement of local disputes through such regional arrangements or by such regional agencies before referring them to the Security Council and, an enforcement action (Zannier 2015: 97). The UN Security Council in return could utilize the OSCE 
to keep fully informed of activities undertaken or in contemplation under regional arrangements or by regional agencies for the maintenance of international peace and security.

When the UN provided such an arrangement in its foundational Charter, it did not consider how this joint-work would function at that time, but that such a juxtaposition would be required for an enhancement and improvement of its respective institutional practices. As the $90 \mathrm{~s}$ are considered a decade marked by a high level of instability in the world due to geopolitical changes after 1989-collapse, the UN was confronted at that time "with an unprecedented number of challenges to stability and peace in many regions of the world" (Zannier 2015: 97). Within this context, as Zannier points out, new approaches to peacemaking and peacekeeping were emerging as part of the $\mathrm{UN}$ role on this matter. Consequently, the UN interests in improving its engagement with regional organizations due to their regional expertise gained in attraction and importance (2015: 97). From that time on, the UN-OSCE joint-work improved what I refer to as juxtaposition among them while defining key strategies in the pursuit of common achievements. After the resolution that gave birth to their joint-work, in 1993 both organizations agreed on the design of the Framework for cooperation and coordination between the United Nations Secretariat and the Conference on Security and Cooperation in Europe (UN Doc. A/48/185).

Therefore, the juxtaposition between the UN and OSCE can be seen as a result of international challenges calling for "new approaches to peacemaking and peacekeeping. Zannier argues that over the past decades the UN and the OSCE have worked together, experienced episodes of success and failure, and shared lessons learned" (Zannier 2015: 97). With regard to current conflicts, "lessons learned" can be applied to the notion that organizations build their institutional capacity in combining successes and failures through the improvement of their partnership.

The strength of the juxtaposition between the UN and the OSCE is in the area of post-conflict recovery through joint Commissions. The resolution points out that the Peacebuilding Commission has been an important opportunity for cooperation and close contact with regional and subregional organizations in post-conflict peacebuilding and recovery (UN Doc. S/RES/1631 (2005)). In this regard, juxtaposition between the UN and the OSCE through the establishment of the Peacebuilding Commission is taken as an important aspect of their role in the field of peacebuilding. Through the resolution, the UN was, just to mention a few, stressing the importance of developing regional and subregional organizations' ability to deploy peacekeeping forces rapidly in support of UN peacekeeping operations and requesting the UN Secretary-General to include, in his regular reporting to the Security Council on peacekeeping and peacebuilding operations under its mandate, assessments of progress in the cooperation between the United Nations and regional and subregional organizations. As it becomes evident, juxtaposition in this case reflects a process in which monitoring and evaluation are inherent part building expertise, establishing cooperation and working through a common agreement on information sharing. 
The second landmark dates to August 2013, when the UNSC Presidential Statement underscored the importance of further developing and strengthening cooperation between the UN and regional organizations in the fields of conflict early warning, prevention (UN Doc. S/PRST/2013/12).

In my perspective, the need for enhancing juxtaposition between the UN and the OSCE lies in the notion that the OSCE is a security organization that has much to offer since it is embedded in a comprehensive security concept encompassing three main dimensions of security: politico-military, economic-environmental and human dimensions (Zennier 2015: 99). Hence, it is an organization built on principles that reinforce the UN-led international order while maintaining close contact at senior and operational levels with numerous UN agencies and institutions (Zennier 2015: 102). These two landmarks gain relevance when the Peacebuilding Fund started its operationalization through the financing of peacebuilding projects in Albania, $\mathrm{BiH}$, Kyrgyzstan, Montenegro, Serbia, Uzbekistan, Tajikistan and the Kosovo territory.

\subsection{Financing and Building Peace}

The above-mentioned Peacebuilding Fund (PBF) is an inherent part of what became labelled as the Peacebuilding Architecture (PBA) under the domain of the UN, in conjunction with the Peacebuilding Commission (PBC) and the Peacebuilding Support Office (PBSO). It was originally conceived when the United Nations' Security Council (UNSC) and General Assembly (UNGA) approved the resolutions establishing the PBC in December 2005 (UN Doc. S/RES/1645 (2005), UN Doc. A/RES/60/180).

In the beginning, the PBF was designed to be a multiyear standing fund for postconflict peacebuilding and to be funded by voluntary contributions. Its focus was on the immediate release of resources needed to launch peacebuilding activities and the availability of appropriate financing for recovery as well as on the support of interventions that were considered critical to the peacebuilding process ((UN Doc. S/RES/1645 (2005), UN Doc. A/RES/60/180), UN Doc. A/60/984).

Despite the fact that the PBF was designed in late 2005, it gained a formal structure only eight months after the adoption of the UNSC and UNGA's decisions on the PBC in August 2006. At that time, the former UN Secretary-General Kofi Annan launched the Arrangements for Establishing the Peacebuilding Fund, which was a document that explained the whole design of the PBF. Financing is an important aspect for peacebuilding since it comes attached to an ideology on what the institution decides must be financed. Money is designated for implementing and disseminating a common agenda, even though this agenda aims at the promotion of peacebuilding. PBF "constitutes a global fund of monies received from voluntary contributions, designed to support several country situations simultaneously" (Lambourne and Herro 2008: 282).

Response Facilities are yet other tools in this context, for example the Immediate Response Facility (IRF) “is designed for wherever peacebuilding opportunities arise 
in the immediate aftermath of political crisis or conflict" (PBSO 2014: 9); and the Peacebuilding Response Facility (PRF), "is applied within several years following the end of a conflict to support national efforts and consolidate peacebuilding" (PBSO 2014: 9).

The difference between them depends on the amount of money donated to a specific country and the timeframe to develop the peacebuilding project or program. Since 2005, the PBF has provided financial support to 61 countries and seven of them are the unique ones that are OSCE-participating states, as it is in the case of Albania, $\mathrm{BiH}$, Kyrgyzstan, Montenegro, Serbia, Uzbekistan, Tajikistan; with support also to the Kosovo territory.

The OSCE role in these countries varies from an agenda centered on justice and electoral reform, the rule of law and progress towards gender equality in Albania (OSCE 2020k: 56), to environmental governance and the consolidation of democratic society in BiH (OSCE 2020k: 58). From intercommunity dialogue and gender equality and youth participation in Kosovo to strengthening democratic institutions and building a free, resilient and professional media in Montenegro, and from an accountable security sector in combating organized crime in Serbia (OSCE 2020k: 60-64). Countering terrorism and transnational threats and border management in Kyrgyzstan and in Tajikistan, and so-called transnational threats, transparency in governance, fighting corruption, combating money laundering in Uzbekistan are part of this mechanism (OSCE 2020k: 80-86).

As Table 2.1 evidences below, 25 projects were financed by the PBF in these respective countries, Kyrgyzstan being the one that received more funding for more diversity-themed projects, emphasizing what the UN peacebuilding agenda

Table 2.1 OSCE-participating States benefited by funding from the PBF

\begin{tabular}{l|l|l|l}
\hline Country & Project theme & $n$ of projects & Amount in US\$ \\
\hline Albania & Emergency-W3 & 1 & $2,999,745$ \\
\hline \multirow{2}{*}{ KiH } & Emergency-W3 & 3 & $5,933,294$ \\
\cline { 2 - 4 } & Democratic Governance & 6 & $8,921,524$ \\
\cline { 2 - 4 } & Security & 6 & $5,424,835$ \\
\cline { 2 - 4 } & Youth Employment/Empowerment & 3 & $4,605,329$ \\
\cline { 2 - 4 } & Public Administration & 1 & 950,200 \\
\cline { 2 - 4 } & PBF Support & 1 & 551,653 \\
\cline { 2 - 4 } & Emergency-W3 & 17 & $23,038,916$ \\
\hline Kosovo & Emergency-W3 & 1 & $2,772,780$ \\
\hline Montenegro & Emergency-W3 & 1 & 946,335 \\
\hline Serbia & Emergency-W3 & 1 & $4,600,000$ \\
\hline Uajbekistan & Emergency-W3 & 1 & 2 \\
\hline Tajistan & Emergency-W3 & 2 & \\
\hline
\end{tabular}

Source UNDP-MPTF (2020) 
is, centered on issues of democratic governance, security, the role of youth, and public administration, just to mention a few.

In addition, the emergency relief (W3) evidenced above is a type of financial support common to the three countries. On this point, I would emphasize that emergency per se is a type of funding that prioritizes the UN peacebuilding agenda under the main clusters evidenced previously but that has a limited amount of money and faces an urgent need.

In the case of $\mathrm{BiH}$, for example, Dialogue for the future: Promoting Coexistence and Diversity was its emergency financial need, in which the project implemented by UNICEF, UNDP and UNESCO in mid-July 2014 would create spaces for dialogue that will enable a country-wide peacebuilding process that promotes coexistence, trust building and appreciation of diversity; increase participation, awareness and influence of youth in policy dialogue on issues impacting B\&H's development and reform agenda; ensure that education supports greater social cohesion; and that citizens and communities advance common peacebuilding goals through culture (UNDP-MPTF 2020).

When this project was implemented in $\mathrm{BiH}$, the OSCE mission was facing antigovernment protests that shook the country in February, and devastating floods and landslides led to the largest post-war humanitarian crisis in May (OSCE Annual Report 2014: 58). One of the responses was to invest in the empowerment and capacity of Youth. The OSCE established the region's first Youth Advisory Group in line with the Swiss Chairmanship priority on youth involvement (OSCE Annual Report 2014: 58). The purpose was to empower youth and stimulating new ideas within the Mission that would serve as a model to be replicated elsewhere in the region (OSCE Annual Report 2014: 58).

Although the CPC and the PBF were not officially partners in the pursuit of peacebuilding, the role of the OSCE mission in $\mathrm{BiH}$ at the same moment the PBF finances a project on enhancing youth role in policy dialogue reflect a synergy that the OSCE designed as part of its approach to peace and to what had been designed by the PBF as a UN model for peacebuilding. In parallel to this project in $\mathrm{BiH}$, the financial support by the PBF also benefited Montenegro and Serbia, while they were implementing the "Dialogue for the Future", which aimed for building social cohesion in and between $\mathrm{BiH}$, Montenegro and Serbia. This means that some projects under the PBF bring an integrative component while dealing with conflict issues that tend to negatively spread to neighboring countries or territories.

The neighboring country of Kosovo faced similar challenges. The PBF allowed for investing in the project Empowering Youth for a Peaceful, Prosperous, and Sustainable Future in Kosovo, which reverberates to the role OSCE plays in the territory. And that youth also became an issue of concern in Albania, with the PBF approved project on "Supporting the Western Balkan's collective leadership on reconciliation: building capacity and momentum for the Regional Youth Cooperation Office (RYCO)".

In Central Asia, in the conflict zone of the Fergana Valley, the inclusion of Uzbekistan under the PBF was for the implementation of Youth for Social Harmony in the 
Fergana Valley", aiming at achieving social cohesion within neighboring communities. Across the border in Tajikistan, the Cross-border Cooperation for Sustainable Peace and Development was an emergency project under the cluster of security the PBF financed for, and co-implemented by, the FAO, UNICEF, UNWOMEN, UNDP and WFP in 2015. It aims to increase cooperation and trust between communities in pilot Tajik-Kyrgyz village clusters towards mitigating immediate risks of renewed cross-border violence (UNDP-MPTF 2020).

Although throughout the OSCE region the UN involvement through its peacebuilding funding apparatus is sensitive to such cross-border projects, this specific theme was an often recurring one under the role of the OSCE in Central Asia. The Desk in Central Asia contributed to a CPC-organized expert assessment mission to Tajikistan in order to identify areas for assistance in strengthening border security and management (OSCE Annual Report 2006: 90). Later, it worked with the Centre in Dushanbe and the Tajikistan authorities on the development of borderrelated projects aimed at strengthening Tajikistan's borders (OSCE Annual Report 2007: 93). In the year of the implementation of the project in Tajikistan through PBF funding, the OSCE office in Tajikistan continued to lead the unique "international initiative providing capacity-building support of an operational, planning and practical nature for border security and management to the Tajik, Afghan and Kyrgyz border services" (OSCE Annual Report 2015: 86).

In the context of the project financed by the PBF, the OSCE office in that country focused on improving border agencies' abilities to detect and interdict illegal crossborder movements across both the Tajik-Afghan and Tajik-Kyrgyz borders (OSCE Annual Report 2015: 86). As the PBF finances projects that aim to address emergent issues based on what have been considered challenging aspects for the role of the OSCE, projects under the PBF do not start from scratch, rather they are built upon needs already mapped by the OSCE in which the PBF engage with.

In the case of Kyrgyzstan, a country within the OSCE region that has benefited the most from the PBF, the Desk office has implemented 17 emergency projects in the context of peacebuilding agenda (Table 2.1). Examples are projects that aim at reinforcing security matters, ${ }^{7}$ youth and women, ${ }^{8}$ and public administration ${ }^{9}$ issues

\footnotetext{
${ }^{7}$ On security, the project approved was Infrastructure for Peace - Policy Dialogue and Preventive Action (Kyrgyzstan).

${ }^{8}$ On youth and women, PBF approved the projects Empowering Youth, Women and Vulnerable Communities to Contribute to Peacebuilding and Reconciliation in Kyrgyzstan, the one on Empowering Youth to Promote Reconciliation and Diversity (Kyrgyzstan); Women Building Peace, Trust and Reconciliation in Kyrgyzstan; Women as Peaceful Voters \& Women as Candidates (Kyrgyzstan); and Building the evidence base to facilitate responsive gender policy and programs for equality and lasting peace in Kyrgyzstan, Women and Girls as Drivers for Peace and Prevention of Radicalization in Kyrgyzstan, Youth as Agents of Peace and Stability in Kyrgyzstan (NUNO), Addressing Social Disparity and Gender Inequality to Prevent Conflicts in New Settlements, Cameras in hand: Transformation and empowerment of Kyrgyzstani girls and boys, Kyrgyzstan's youth cohesion and interaction towards Uzbekistan, Strengthening capacity of young women and men in Kyrgyzstan to promote peace and security, and Empowering women.

${ }^{9}$ On public administration: the project is Administration of Justice (Kyrgyzstan).
} 
in the country; combined with projects on minor issues such as natural resources ${ }^{10}$ and media. ${ }^{11}$

Since the PBF became involved in the OSCE region through the financing of projects considered of great importance for the role in Kyrgyzstan, the PBF also financed a similar project in the neighboring Tajikistan under the same title: Cross-border Cooperation for Sustainable Peace and Development. These similar projects in both countries are being implemented by UN agencies: FAO, UNICEF, UNWOMEN, UNDP and WFP. In both countries, these projects "aims to increase cooperation and trust between communities in pilot Tajik-Kyrgyz village clusters towards mitigating immediate risks of renewed cross-border violence." (UNDP-MPTF 2020).

As cross-border violence and conflicts are a common challenge for both Tajikistan and Kyrgyzstan, not divergent, this issue of concern was a recurrent one with regard to the engagement of the OSCE-CPC in that country. The scenario was marked by a role played by the Central Asia Desk which conducted a Barrier-2015 border security exercise in August 2015 in partnership between the Centre and Kyrgyz authorities, and in close co-ordination with the OSCE Office in Tajikistan (OSCE Annual Report 2015: 84).

The examples taken from the projects financed by the PBF in $\mathrm{BiH}$, Kyrgyzstan and Tajikistan and, in parallel, through the role and engagement of the CPC in these respective countries enable an understanding of where lies the juxtaposition between the UN and the OSCE in the field of peacebuilding.

The analysis is based on the first decade of the PBA (2005-2015) and, hence, prioritizes the same timeframe for analyzing CPC's role in the same countries PBF engaged with. There is no information of close collaboration among the PBF and the $\mathrm{CPC}$ with regard to this specific peacebuilding work. It does not neglect the fact that the PBF and the CPC coexist, but that the partnership among them is restricted to a partnership of a different UN department rather than the UN Peacebuilding Architecture. As the OSCE Annual Report 2007 already points out, the experiences in mediation and conflict resolution among the UN and the OSCE includes a cooperation with the UN Department of Political Affairs (DPA) and the Geneva Centre for Security Policy (GCSP) in organizing high-level consultations to draw key lessons in the OSCE's area (OSCE Annual Report 2007 (2008: 93)). It can be stated that in the evolutionary aspect of the peacebuilding within the UN, the DPA — created in 1992 was slowly transforming into a peacebuilding concept by UN, following the reform of the United Nations peace and security infrastructure, bringing it together with United Nations Peacebuilding Support Office (DPPA 2020b), which is the manager of the PBF.

\footnotetext{
${ }^{10}$ On water, PBF approved the Cultivating Peace - Using Water-based Agriculture to Facilitate Reconciliation among Multi-ethnic Residents of Kara Suu (Kyrgyzstan).

${ }^{11}$ On media, the project approved was Strengthening Media Capacity to Promote Peace and Tolerance in the Kyrgyz Republic.
} 


\subsection{OSCE-UN Partnerships}

So far the partnership between the UN and the OSCE has evolved as a result of what both organizations do in juxtaposition with each other. Based on BiH, Kyrgyzstan and Tajikistan, the Peacebuilding Fund provided financial support to projects that could represent a dissemination of the institutional values of the UN and at the same time enhance a peacebuilding agenda in these respective countries through a jointwork with agencies and local actors that identify challenging and promising issues to be coopted by the PBF. As became evident from the three OSCE-participating States, there is a cooptation of the UN agenda for peacebuilding and of what the $\mathrm{PBF}$ finances in the scenario OSCE operates through the $\mathrm{CPC}$, creating a space for a common ground on projects for peacebuilding.

Based on Lambourne and Herro's analysis of the Australian-led Regional Assistance Mission to the Solomon Islands (RAMSI) and on the US-led interventions in Iraq and Afghanistan, these and other interventions operating outside the UN framework "need to make a particular effort to learn from the UN's extensive experience and to incorporate the priorities identified by peacebuilding theory and best practice, which are being consolidated in the operations of the PBC" (2008: 288). Although they mention the PBC as a reference for UN framework intervention, I would say that it is on the PBF that the framework for peacebuilding becomes more explicit since the PBF is the channel through which countries face eligibility for their respective peacebuilding projects, interact with different UN agencies and local actors in designing the projects, get money for implementing the projects and, hence, coopt an agenda for peacebuilding through the engagement of different organizations rather than the UN.

One can conclude that by lessons learned, the UN intervention framework can work as an external perspective in which the OSCE could adapt to this reality. The OSCE's role, through the engagement of other UN agencies, and as the PBF does through its financial apparatus, is a strategy that could enhance not only the juxtaposition between them, but put the OSCE in a leading position of acting proactively in the region.

Since the PBF depends on voluntary contributions by UN-member states, in the beginning of this chapter I mentioned that juxtaposition reflects that being an OSCEparticipating States is a labelled condition in which such label cannot be easily detached from these countries, even though they interact in different international organizations rather than the OSCE. In this specific case, the Peacebuilding Fund is not only a UN body dealing with financing for peacebuilding, but a platform in which OSCE-participating States co-exist, be they donors or recipients of PBF funding.

Table 2.2 illustrated that from the 57 OSCE-participating States, only 29 engaged with the PBF as donors. The OSCE plays a role in the functioning of the PBF, but the amount UN-member states donate for peacebuilding reflects their level of interest in enhancing peacebuilding through the UN framework.

By level of interest by the UN-member states, it can be illustrated that these $\mathrm{UN}-$ members do not directly fund projects in specific countries through the PBF, 
since the PBF finances projects designed under its peacebuilding framework which are institutionally evaluated and scrutinized. What is in question is that the PBF was created for countries facing post-conflict challenges and this notion permeates and motivates UN-member states in their decisions for financing the PBF. Shown below, Sweden and Germany donate the most, followed by countries such as United Kingdom and the Netherlands.

Based on Table 2.2 above, Western European countries are the main donors to the PBF, in contrast to what the PBF receives from Russia, Canada and the United States, respectively (UNDO-MPTF 2020). The point, here, is to evidence that the amount donated by all of them reflects not only what these countries prioritize for peacebuilding and, mainly, how their financial apparatus to peacebuilding through multilateralism impacts on the UN and OSCE role on this field.

Table 2.2

OSCE-participating States $^{12}$ as donors to the PBF (2005-2020)

\begin{tabular}{l|l|l|l}
\hline Austria & $2,108,550$ & Netherlands & $123,055,332$ \\
\hline Belgium & $8,057,228$ & Norway & $88,463,975$ \\
\hline Canada (CIDA) & $33,855,496$ & Poland & 580,235 \\
\hline Canada (Gov.) & $25,183,829$ & Portugal & $1,069,280$ \\
\hline Croatia & 148,000 & Romania & 147,210 \\
\hline Cyprus & 40,000 & Russia & $18,000,000$ \\
\hline Czech Republic & 356,399 & Slovakia & 756,828 \\
\hline Denmark & $35,609,871$ & Slovenia & 41,688 \\
\hline Estonia & 608,028 & Spain & $17,917,677$ \\
\hline Finland & $28,286,519$ & Sweden & $208,252,105$ \\
\hline France & $5,239,740$ & Switzerland & $10,334,452$ \\
\hline Germany & $183,742,480$ & Turkey & $2,900,000$ \\
\hline Iceland & $1,000,000$ & UK (DFID) & $156,111,710$ \\
\hline Ireland & $24,887,958$ & UK (Gov.) & $60,108,240$ \\
\hline Italy & $9,565,992$ & United States & 550,000 \\
\hline Luxembourg & $6,680,330$ & & \\
\hline Source UNDP-MP & & & \\
\hline
\end{tabular}

Source UNDP-MPTF (2020). All amounts in US\$ from 2005 to October 2020

\footnotetext{
12 The OSCE-participating States that did not engage with the PBF in financial terms during the period in analysis: Andorra, Armenia, Azerbaijan, Belarus, Bulgaria, Georgia, Greece, Holy See, Hungary, Kazakhstan, Latvia, Liechtenstein, Lithuania, Malta, Moldova, Monaco, Mongolia, North Macedonia, San Marino, Turkmenistan and Ukraine (OSCE 2020j).
} 


\subsubsection{Conclusion}

The perspective on juxtaposition between the UN and the OSCE through the Peacebuilding Fund and the Conflict Prevention Center, respectively, enables an understanding that institutional decisions on establishing liaison offices abroad reflect a strategy of diffusion of organizational values and agenda based on a permanent cooperation partnership.

The evidence through the role the OSCE plays in countries that benefited from the PBF, such as Albania, BiH, Kyrgyzstan, Montenegro, Serbia, Uzbekistan, Tajikistan and the Kosovo territory, as well as the peacebuilding agenda PBF finances in countries and territory included in the OSCE region, enables identifying what both organizations understand as being their peacebuilding approaches.

As illustrated in this chapter, the UN involvement in Europe and the OSCE region is underrepresented in comparison to its role in countries in the Africa continent, for example. The UN counts heavily on the peacebuilding engagement of the OSCE and its donors in the region. In respect to Africa, countries concentrate more than $50 \%$ of the financial support through the PBF as well as in the quantity of projects financed. In this regard, the role of the Peacebuilding Fund in countries such as Albania, BiH, Kyrgyzstan, Montenegro, Uzbekistan, Tajikistan and Kosovo territory, emphasize how the UN has designed its peacebuilding agenda during the functioning of the UN Peacebuilding Architecture. Its engagement in parallel to the engagement of the OSCE in these respective countries contributed to identify challenges that the PBF could provide support for in alignment to its peacebuilding agenda.

To conclude, the UN and OSCE complement each other through what they design for their respective peacebuilding approaches. It is important to affirm that this complementarity is far from being perfect due to the domain the UN has in the field of peacebuilding. Nevertheless, the promising aspect among them puts both organizations far from competing in this domain, hence the UN withholds its scarce resources and funds wherever the OSCE and its overall Western European member states jump into. This also avoids not only double funding by member-states, but legitimizes the UN decision on launching a Liaison Office in Vienna in order to more closely coordinate the partnership with the OSCE.

Acknowledgements I express my gratitude for the Foundation for Science and Technology (FCT-Portugal) for financing my four-years scholarship as part of the Ph.D. Program in International Politics and Conflict Resolution at the University of Coimbra (2015/2019) under the reference PD/BD/113981/2015. My gratitude also to Dr. Anja Mihr and all editors and professional proofreaders for their cautious review and suggested improvements for this chapter. 


\section{References}

CSCE (1990) Charter of Paris for a New Europe. Retrieved from www.osce.org/files/f/documents/ 0/6/39516.pdf. First Access on 10 August, 2020

CSCE (1975) Final Act. Helsinki. Retrieved from www.osce.org/files/f/documents/5/c/39501.pdf. First Access on 10 August, 2020

CSCE (2020) Confidence and security building measures. Retrieved from www.osce.org/secret ariat/107484. First Access on 10 August, 2020

DPPA (2020a). Organization for Security and Co-operation in Europe at the UN. Retrieved from https://dppa.un.org/en/organization-security-and-co-operation-europe. First Access on 10 August, 2020

DPPA (2020b) Peacebuilding and Political Affairs. Retrieved from https://dppa.un.org/en/about-us. First Access on 10 August, 2020

OSCE Doc. MC.DEC/3/11. Elements of the conflict cycle, related to enhancing the OSCE's capabilities in early warning, early action, dialogue facilitation and mediation support, and postconflict rehabilitation. Organization for security and co-operation in Europe. Ministerial Council. Second day of the Eighteenth Meeting. Retrieved from https://www.osce.org/files/f/documents/ 6/b/86621.pdf. First Access on 13 August, 2020

OSCE (2006a) Annual Report on OSCE Activities 2005. Retrieved from https://www.osce.org/ files/f/documents/5/a/18847.pdf. First Access on 13 August, 2020

OSCE (2006b) Environmental concerns in Ferghana valley to top agenda of OSCE meeting in Bishkek. Retrieved from www.osce.org/eea/47095. First Access on 13 August, 2020

OSCE (2007). OSCE Annual Report on OSCE Activities 2006. Retrieved from https://www.osce. org/files/f/documents/3/e/24692.pdf. First Access on 13 August, 2020

OSCE (2008) Annual Report on OSCE Activities 2007. Retrieved from https://www.osce.org/files/ f/documents/e/9/31249.pdf. First Access on 13 August, 2020

OSCE (2009) Annual Report on OSCE Activities 2008. Retrieved from https://www.osce.org/files/ f/documents/3/d/36699.pdf. First Access on 13 August, 2020

OSCE (2010) Annual Report on OSCE Activities 2009. Retrieved from https://www.osce.org/files/ f/documents/2/2/67759.pdf. First Access on 13 August, 2020

OSCE (2011) Annual Report on OSCE Activities 2010. Retrieved from https://www.osce.org/files/ f/documents/8/f/76315.pdf. First Access on 13 August, 2020

OSCE (2012) Annual Report on OSCE Activities 2011. Retrieved from https://www.osce.org/files/ f/documents/a/d/89356.pdf. First Access on 13 August, 2020

OSCE (2013) Annual Report on OSCE Activities 2012. Retrieved from https://www.osce.org/files/ f/documents/2/2/100193.pdf. First Access on 13 August, 2020

OSCE (2014) Annual Report on OSCE Activities 2013. Retrieved from https://www.osce.org/files/ f/documents/7/4/116947.pdf. First Access on 13 August, 2020

OSCE (2015) Annual Report on OSCE Activities 2014. Retrieved from https://www.osce.org/files/ f/documents/0/4/169971.pdf. First Access on 13 August, 2020

OSCE (2016) Annual Report on OSCE Activities 2015. Retrieved from https://www.osce.org/files/ f/documents/3/4/240126.pdf. First Access on 13 August, 2020

OSCE (2017) OSCE Annual Report 2016. Retrieved from www.osce.org/files/f/documents/3/d/310 856.pdf. First Access on 13 August, 2020

OSCE (2018) OSCE Annual Report 2017. Retrieved from www.osce.org/files/f/documents/7/0/375 964_0.pdf. First Access on 13 August, 2020

OSCE (2019) OSCE Annual Report 2018. Retrieved from www.osce.org/files/f/documents/6/c/416 624_0.pdf. First Access on 13 August, 2020

OSCE (2020a) Minsk group. Press statement by the co-chairs of the OSCE Minsk group. Retrieved from www.osce.org/minsk-group/463533. First Access on 5 November, 2020

OSCE (2020b) Minsk group. Press statement by the co-chairs of the OSCE Minsk group. Retrieved from www.osce.org/minsk-group/465018. First Access on 5 November, 2020 
OSCE (2020c) Minsk group. Special meeting of OSCE permanent council held on situation in Nagorno-Karabakh context. Retrieved from www.osce.org/chairmanship/465225. First Access on 5 November, 2020

OSCE (2020d) Minsk group. Statement by the co-chairs of the OSCE Minsk group. Retrieved from www.osce.org/minsk-group/465711. First access on 5 November, 2020

OSCE (2020e) Minsk group. statement by the co-chairs of the OSCE Minsk Group. Retrieved from www.osce.org/minsk-group/465879. First Access on 5 November, 2020

OSCE (2020f) Minsk group. Statement by the co-chairs of the OSCE Minsk group. Retrieved from www.osce.org/chairmanship/466737. First Access on 5 November, 2020

OSCE (2020g) Minsk group. Statement by the co-chairs of the OSCE minsk group. Retrieved from www.osce.org/minsk-group/466998. First access on 5 November, 2020

OSCE (2020h) Minsk group. Press statement by the co-chairs of the OSCE Minsk Group. Retrieved from www.osce.org/minsk-group/468204. First Access on 5 November, 2020

OSCE (2020i) Minsk group. Press statement by the Co-Chairs of the OSCE Minsk Group. Retrieved from www.osce.org/minsk-group/468984. First Access on 5 November, 2020

OSCE (2020j). Factsheet of the OSCE conflict prevention centre. Retrieved from www.osce.org/ cpc/13717. First Access on 10 August, 2020

OSCE (2020k) OSCE annual report 2019. Retrieved from www.osce.org/files/f/documents/0/9/449 104_0.pdf. First Access on 5 November, 2020

OSCE (20201) Border management. Retrieved from www.osce.org/programme-office-in-dushanbe/ 106426. First Access on 5 November, 2020

PBSO (2014) United nations Peacebuilding Fund (PBF). Guidelines on application and use of funds. Retrieved from www.unpbf.org/wp-content/uploads/PBF-Guidelines-Final-April-20141. pdf. First Access on 20 August, 2016

UN (1945) Charter of the united nations and statute of the international court of justice. Retrieved from https://treaties.un.org/doc/publication/ctc/uncharter.pdf. First Access on 10 August, 2020

UN (1992) A/47/277-S/24111. An agenda for peace: preventive diplomacy, peacemaking and peacekeeping: report of the Secretary-General pursuant to the statement adopted by the Summit Meeting of the Security Council on 31 January 1992. Retrieved from https://undocs.org/en/A/47/277. First access on 10 August, 2020

UN (2000) A/55/305-S/2000/809. Report of the Panel on United Nations Peace Operations. Retrieved from https://undocs.org/A/55/305. First Access on 10 August, 2020

UN Doc. A/48/185. Cooperation between the United Nations and the Conference on Security and Cooperation in Europe. Retrieved from https://undocs.org/A/48/185. First Access on 10 August, 2020

UN Doc. A/60/984. Arrangements for Establishing the Peacebuilding Fund. Report of the SecretaryGeneral. Retrieved from https://www.undocs.org/A/60/984. First Access on 10 August, 2020

UN Doc. A/RES/47/10. Cooperation between the United Nations and the Conference on Security and Cooperation in Europe. Retrieved from https://undocs.org/A/RES/47/10. First Access on 10 August, 2020

UN Doc. A/RES/60/180. Resolution adopted by the General Assembly on 20 December 2005. The Peacebuilding Commission. Retrieved from https://undocs.org/A/RES/60/180. First Access on 10 August, 2020

UN Doc. S/PRST/2013/12. Statement by the President of the Security Council. Retrieved from https://www.undocs.org/S/PRST/2013/12. First Access on 10 August, 2020

UN Doc S/RES/1244 (1999). Resolution 1244 (1999) Adopted by the Security Council at its 4011th meeting, on 10 June 1999. Retrieved from http://unscr.com/en/resolutions/doc/1244. First Access on 10 August, 2020

UN Doc. S/RES/1631(2005) Resolution 1631 (2005), Adopted by the Security Council at its 5282nd meeting, on 17 October 2005. Retrieved from https://www.undocs.org/S/RES/1631(2005). First Access on 10 August, 2020. 
UN Doc. S/RES/1645(2005). Resolution 1645 (2005) Adopted by the Security Council at its 5335th meeting, on 20 December 2005. Retrieved from https://undocs.org/S/RES/1645(2005). First Access on 10 August, 2020

UNDP-MPTF (2020) Multi-partner trust fund office. Trust fund factsheet. The peacebuilding fund. Gateway. Retrieved from http://mptf.undp.org/factsheet/fund/PB000. First Access on 10 August, 2020

\section{Secondary Sources}

Ackermann A (2003) The prevention of armed conflicts as an emerging norm in international conflict management: the OSCE and the UN as Norm Leaders. Peace and Conf Stud 10(1), 1. Retrieved from https://nsuworks.nova.edu/pcs/vol10/iss $1 / 1$

Ackermann A (2010) OSCE mechanisms and procedures related to early warning, conflict prevention, and crisis management. IFSH (ed.), OSCE Yearbook 2009, Baden-Baden, pp 223-231

Ackermann A (2013) Strengthening OSCE responses to crises and conflicts: an overview. IFSH (ed.), OSCE Yearbook 2012, Baden-Baden, pp 205-211

Askerov A (2020) The Nagorno Karabakh conflict: the beginning of the soviet end, in Askerov, brooks and Tchantouridze (eds.), Post-soviet conflicts: the thirty years crisis. Lanham, Lexington Brooks, 55-82

Bekiarova N, Armencheva I (2019) Is the peaceful regulation of the Nagorno-Karabakh conflictmission possible? In: Proceedings of INTCESS 2019- 6th International Conference on Education and Social Sciences, 4-6 February 2019. Dubai, U.A.E. ISBN: 978-605-82433-5-4, Available at SSRN: https://ssrn.com/abstract=3332351

Cavanaugh C (2017) Renewed conflict over Nagorno-Karabakh, council on foreign relations. Retrieved from www.jstor.com/stable/resrep05705

Cohen J (1999) Conflict prevention in the OSCE: an assessment of capacities. Netherlands Institute of International Relations Clingendael, The Hague

Galtung J (1976) Three approaches to peace: peacekeeping, peacemaking and peacebuilding. Peace, war and defense: essays in peace research, vol 2, Copenhagen, Ejlers, pp 282-304

Gheciu A (2008) Securing Civilization? The EU, NATO, and the OSCE in the Post-9/11 World. Oxford University Press, New York

George B, McGee A (2006) The OSCE's approach to conflict prevention and postconflict rehabilitation, in Mason T David, Meernik James D (eds.) Conflict prevention and peacebuilding in post-war societies: sustaining the peace. New York, Routledge, pp 81-104

Krampe F (2019) Climate change, peacebuilding and sustaining peace, SIPRI Policy Brief. Retrieved from www.sipri.org/sites/default/files/2019-06/pb_1906_ccr_peacebuilding_2.pdf

Lambourne W, Herro A (2008) Peacebuilding theory and the United Nations peacebuilding commission: implications for non-UN interventions. Glob Change, Peace \& Sec Formerly Pacifica Rev Peace, Sec Glob Chan 20(3):275-289. https://doi.org/10.1080/14781150802390467

Rácz A (2020) War in Nagorno-Karabakh: a two-track strategy for the EU, DGAP CommentaryGerman Council on Foreign Relations, no 3, October 2020. Retrieved from https://dgap.org/en/ research/publications/war-nagorno-karabakh. Accessed on 10 November 2020

Roth A, Safi M (2020) Nagorno-Karabakh peace deal reshapes regional geopolitics, The Guardian. Retrieved from www.theguardian.com/world/2020/nov/10/nagorno-karabakh-peacedeal-turkey-russia-reshapes-regional-geopolitics. Accessed on November 2020

Sherman J, Krampe F (2020) The peacebuilding commission and climate-related security risks: a more favourable political environment? SIPRI-IPI Insights on Peace and Security. Retrieved from www.sipri.org/sites/default/files/2020-09/sipriinsight2009_pbc_and_climate-related_secu rity_risks_v2_0.pdf 
Steinmeier F-W (2016) Not a concert of powers, but an ensemble of peace: what we can learn from Helsinki for European security in the 21st century. IFSH (ed.), OSCE Yearbook 2015, Baden-Baden, pp 23-34

Tanner F (2016) The OSCE and the Crisis in and around Ukraine: first lessons for crisis management, in: IFSH (eds.), OSCE Yearbook 2015, Baden-Baden 2014, pp 241-250

Van Hoye E (1999) The OSCE in the Caucasus: long-standing mediation for long-term resolutions, In: IFSH (ed.), OSCE Yearbook 1999, Baden-Baden 2000, pp 247-256

Vieira M (2020a) Framing the fragmentation of peace: an analysis of the UN Sustainable Development Goals (SDGs), Meridiano 47. J Glob Stud 21. Retrieved from https://doi.org/10.20889/ M47e21005

Vieira M (2020b) Reflecting on the role of the United Nations peacebuilding fund in Africa, conflict trends 2020/2. Retrieved from https://www.accord.org.za/conflict-trends/reflecting-on-the-roleof-the-united-nations-peacebuilding-fund-in-africa/. Accessed 13 Aug 2020

Zannier L (2015), The OSCE and chapter VIII of the United Nations charter-contributing to global peace and security. In: IFSH (ed.), OSCE Yearbook 2014, Baden-Baden 2015, pp 97-109

Open Access This chapter is licensed under the terms of the Creative Commons Attribution 4.0 International License (http://creativecommons.org/licenses/by/4.0/), which permits use, sharing, adaptation, distribution and reproduction in any medium or format, as long as you give appropriate credit to the original author(s) and the source, provide a link to the Creative Commons license and indicate if changes were made.

The images or other third party material in this chapter are included in the chapter's Creative Commons license, unless indicated otherwise in a credit line to the material. If material is not included in the chapter's Creative Commons license and your intended use is not permitted by statutory regulation or exceeds the permitted use, you will need to obtain permission directly from the copyright holder. 